\begin{abstract}
Iranica
Abstracta Iranica Revue bibliographique pour le domaine irano-aryen

Volume 40-41 | 2019

Comptes rendus des publications de 2017-2018
\end{abstract}

\title{
Nancy Shatzman Steinhardt. China's Early Mosques
}

\section{Yuka Kadoi}

\section{(2) OpenEdition \\ Journals}

Electronic version

URL: http://journals.openedition.org/abstractairanica/49565

DOI: 10.4000/abstractairanica.49565

ISBN: 1961-960X

ISSN: 1961-960X

Publisher:

CNRS (UMR 7528 Mondes iraniens et indiens), Éditions de l'IFRI

Electronic reference

Yuka Kadoi, "Nancy Shatzman Steinhardt. China's Early Mosques", Abstracta Iranica [Online], Volume 40-41 | 2019, document 8, Online since 30 October 2019, connection on 21 April 2021. URL: http:// journals.openedition.org/abstractairanica/49565 ; DOI: https://doi.org/10.4000/abstractairanica. 49565

This text was automatically generated on 21 April 2021.

Tous droits réservés 


\title{
Nancy Shatzman Steinhardt. China's Early Mosques
}

\author{
Yuka Kadoi
}

\section{REFERENCES}

Nancy Shatzman Steinhardt. China's Early Mosques. Edinburgh: Edinburgh University Press, 2018, 331 p., +200 ill., ISBN: 9781474437219

1 China's Early Mosques is one of the latest additions to the Edinburgh Studies in Islamic Art and among the most unique publications in the field of so-called "Islamic architecture" in recent years. While the history of Middle Eastern (i.e. Iran, Turkey and the Arab world) architecture since the seventh century remains the focal point in this field of research, Steinhardt enters the field from East Asia. As a study of Chinese architectural history, too, China's Early Mosques is far too unique to be published in the English-speaking world, and indeed it is the first publication of this kind to be written in non-East Asian languages. The mechanisms of adoption and adaptation in MuslimChinese architectural encounters were almost never satisfactorily addressed in the past, neither by Chinese architectural historians, nor by Islamic Middle Eastern architectural historians.

2 The aim of this book sounds straightforward: in order to understand what happened when monotheistic, foreign religions were granted permission to build their place of worship in non-monotheistic, homogenous civilisations in which building tradition has been largely unchanged for several millennia, it explains how the environmental requirement of the Muslim community and the traditional architectural system of China converged. The architectural transformation of Chinese mosques occurred in parallel with the change of rulership, each with a different political and religious agenda, and the most radical alteration took place during the fifteenth and sixteenth centuries, when the cosmopolitan ambient under the Yuan dynasty was given away to cultural conservatism under the Ming dynasty. Ironically, though, thanks to their 
successful incorporation into the traditional Chinese architectural system, often acquiring the guise of Buddhist and Daoist temples, the mosques - and ultimately Islam itself - have survived in China until today.

3 The book is divided into eleven chapters: 1) Muslims, Mosques and Chinese Architecture; 2) China's Oldest Mosques; 3) China's Other Early Mosques; 4) Mongols, Mosques and Mausoleums; 5) Xi'an and Nanjing: Great Mosques and Great Ming Patrons; 6) Ox Street Mosque and Muslim Worship in or Near Beijing; 7) China's Most Important Yuan and Ming Mosques; 8) Mosques and Qubbas in Ningxia, Gansu and Qinghai; 9) Xinjiang: Architecture of Qing China and Uyghur Central Asia; 10) Mosque, Synagogue, Church: Architecture of Monotheism in China; and 11) Conclusion: The Chinese Mosque in the Twenty-First Century.

4 In the preface, Steinhardt tells us about her first encounter with the mosque in Taipei in the 1970s, and it was this encounter that stirred the author to write about the mosque architecture of China. The reviewer also received much of an indelible impression of the Taipei Grand Mosque on Xinsheng South Road: even though Chinese Islam is nowadays becoming a topical subject of research, the unusual appearance of the Taipei Mosque - neither traditionally Chinese, nor typically Islamic - continues to arouse the researchers' curiosity and inquisitiveness.

5 Chapter 1 outlines the architectural foundation of China up to the tenth century and compares between the Chinese space of worship and the Muslim space of worship. The outset of this book is more than satisfactory, in particular to those who seek a good guidance to the topic. Each chapter introduces the selection of mosques and other monotheistic buildings, and the total of 70-80 mosques, ranging from the oldest extant mosques in Quanzhou and Guangzhou to contemporary examples, built as essentially Islamic rather than eclectically Sino-Islamic, are put into historical contexts. In each case, Steinhardt takes care of various topics in such a lucid manner, making sure that the reader would not derail reading. The fascinating architectural dynamics introduced by each chapter could be easily explored further, as a subject of separate articles. Similarly, the comparative analysis of church and synagogue architecture in China in Chapter 10 is equally valuable in its own right and is well worth a separate, monographlength study.

6 As a book of architectural history, the rich selection of photographs and maps, mostly in colour, as well as black-and-white architectural plans and drawings, serves to complement the investigation of each building. Finally, the list of 24-page "select" references is truly amazing: it covers most of the essential publications on this subject, including those written in Chinese, English and other languages. From the viewpoint of East Asian historians, however, it is unfortunate that all of the original Chinese publication titles and terms in both the bibliography and the glossary are transliterated into the Latin alphabet in this magnificent book, which is, after all, concerned with the history of Chinese architecture. Pinyin would help to pronounce a Chinese word, yet it does not necessarily enhance the recognition of its Chinese character. It is hoped that any future publications on the multifaceted topics such as the mosque architecture of China could include the titles of references and terminologies in non-European languages, as they are originally published.

7 China's Early Mosques is a highly original account of global architectural history. It offers an innovative transregional perspective and deserves to be seen as a milestone to 
bridge the convergence of not only Chinese and Islamic architectural traditions but also their respective disciplines.

\section{AUTHORS}

\section{YUKA KADOI}

University of Vienna 